Lars Richter

\title{
The Rebel Girl and the Wrecking Ball - The Cruel Optimism of Empowerment and the Revival of Feminism in Contemporary Popular Music
}

\begin{abstract}
n August 2013, NYC based rock band The Julie Ruin released the
video for "Oh Come On" as a preview to their first album Run Fast. It shows the band performing their song against a plain background
\end{abstract} with a set of Christmas lights shaped to read the name of the band as the most spectacular visual. While sharing the frame with the band, taking front and center stage is The Julie Ruin's lead singer Kathleen Hanna (see fig. 1). In the early 1990s, Hanna had been a member of punk rock band Bikini Kill, one of the seminal representatives of the Riot Grrrl-movement. ${ }^{\text {The }}$ Thelease of "Oh Come On" marked the return of Kathleen Hanna after an eight year hiatus from making music due to a serious case of Lyme disease, a potentially lethal bacterial infection (Anderson, The Punk Singer). The video's release also coincided with a renewed interest in the Riot Grrrl-movement that, twenty years after the movement's peak, inspired a rediscovery by audiences. In 2011, Bikini Kill's first album Pussy Whipped celebrated its twentieth anniversary and

\footnotetext{
${ }^{1}$ Riot Grrrl was a feminist figuration of the punk subculture that first emerged in Olympia, WA and Washington D.C. in the early 1990s. For a history of the Riot Grrrl movement, see Sara Marcus' Girls to the Front (2010).
} 
became subject to considerable media attention. ${ }^{2}$

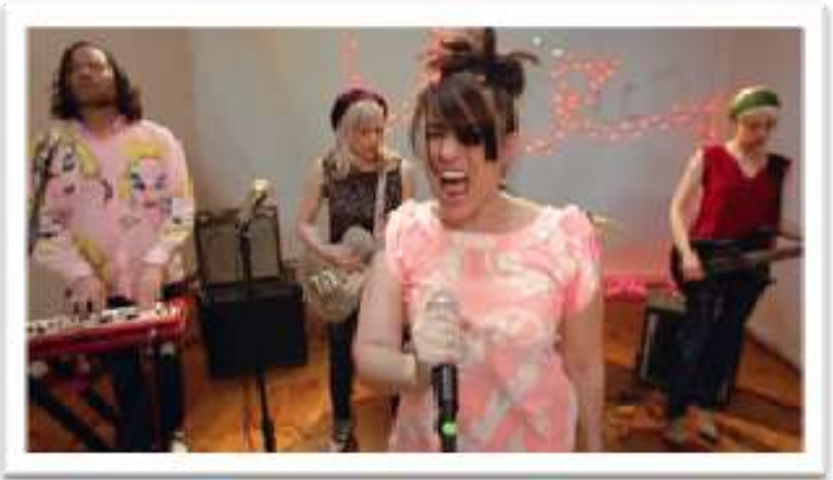

Figure 1: The Julie Ruin with Kathleen Hanna (center) performing "Oh Come On.” The Julie Ruin. "Oh Come On.” YouTube. 5 August 2013. Web. 24 October 2014.

<http://www.youtube.com/watch?v=hEltsPb8M6Q>.

The same year, the Fales Library in NYC opened its "Riot Grrrl Collection," a comprehensive collection of fanzines, videos, images, and music clips from the movement's heyday. In 2012, director Sini Anderson released the documentary The Punk Singer that focuses on Hanna. In 2013, editor Lisa Darms published a compilation of the Fales Library's collection of fanzines, articles, and flyers. While Hanna was appreciative of the way her return to the spotlight and the legacies of the Riot Grrrls was received 3 , she was at the same time aware that the rejuvenated interest also had an air of musealization and historicization about it, a fate that the once rebellious rock 'n' roll in general and punk as its subcultural figuration have suffered by now.4 In an interview with Sonic Youth

\footnotetext{
${ }^{2}$ See for example the contributions by Tom Breihan and Rachel Smith.

3 In an interview with online music magazine Pitchfork, Hanna states, "The '9os are back and people are rediscovering Riot Grrrl for the first time. In terms of our band, I feel that we're being much more appreciated right now in 2013 than in 1994" (“+1" Pitchfork.tv).

4 For the relationship between rock and museums, see Reynolds (2011).
} 
bass-player Kim Gordon, Hanna deemed it "totally bizarre" to be historicized at age 44 and to be solely associated with the 1990 (Gordon).

When The Julie Ruin's debut album Run Fast was released in September 2013, one month after the premiere of "Oh Come On," mainstream media attention shifted towards another video. More than one million people gathered in front of their TV sets, monitors, and displays to watch Miley Cyrus' "Wrecking Ball” (see fig. 2) which, in stark contrast to The Julie Ruin's low-key DIYaesthetics, had a visual style more reminiscent of glossy fashion and lifestyle magazines like Vogue or Cosmopolitan. Comprised of shots of a lightly clad Miley Cyrus swinging on the eponymous wrecking ball through a stylized video set, the video provoked a significant, if short-lived, media scandal.

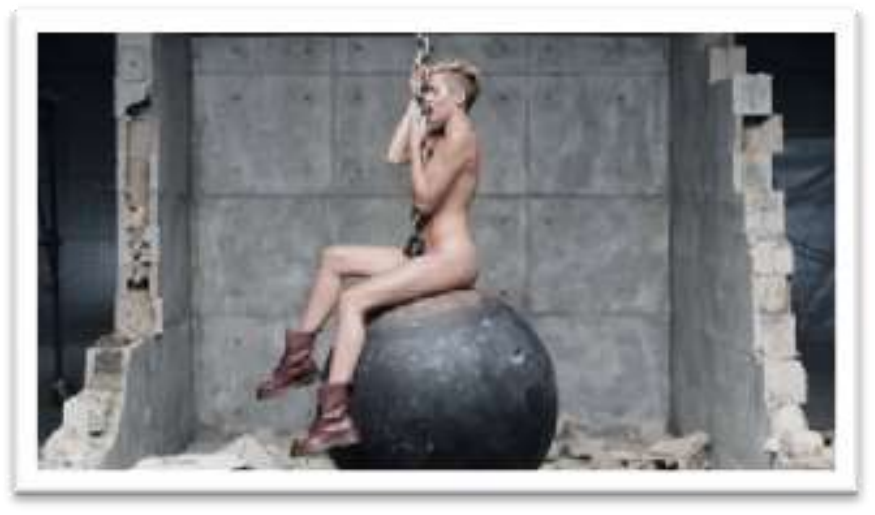

Figure 2: Screenshot from Miley Cyrus' "Wrecking Ball." Cyrus, Miley. "Wrecking Ball." YouTube. 9 September 2013. Web. 24 October 2014. 〈http://www.youtube.com/watch?v=My2FRPA3Gf8>. 
Watching these very distinct videos within such a short time appeared to be an accelerated version of the development from "Revolution Girl Style Now"5 embodied by the Riot Grrrls to the defused and commodified a la Spice Girls "Girl Power" that audiences had witnessed in the 1990s. Arguably the most interesting aspect of the media debate triggered by the release of Cyrus' video was the creation of a field of discursive tension in which the notion of what feminism and, in extension, feminist art means in the twenty-first century was negotiated. Among others, this field of tension was populated by artists like Cyrus herself and Irish singer Sinéad O'Connor who expressed opposing views on the figuration of feminist art, especially with regards to the use of eroticized imagery. Using the different aesthetics of The Julie Ruin's and Cyrus' video as a starting point, I will explore how the almost simultaneous debate surrounding Cyrus' video, the return of Kathleen Hanna, and the concomitant rediscovery of the Riot Grrrl-movement created a point of convergence of two generations of feminist artists that revealed tensions steeped in feminist history while, at the same time, suggesting possible futures for feminist artistic expression.

To problematize the use of eroticized imagery in Cyrus's music video I will turn to Laurent Berlant's helpful notion of cruel optimism to illustrate why and how said imagery as a means of empowerment is not always successful. In a second step, I will revisit the legacies of the Riot Grrrl movement to explore how it has influenced not only contemporary feminist musicians but feminist political protest as well. Lastly, I will explore how the return of Kathleen Hanna,

5 “Revolution Girl Style Now!” was the title of Bikini Kill’s first release in 1991. 
the emergence of new feminist artists as well as new collaborations can open up potential futures for feminist artistic expression.

\section{"Wrecking Ball" and the Cruel Optimism of Empowerment}

The video for "Wrecking Ball" was released on September 9, 2013. It was declared the most popular video of 2013 by the music website Vevo which hosts the clip (news.com.au) and by April 2015, more than 760 million viewers had seen the video. As mentioned above, in contrast to the low-key approach The Julie Ruin had chosen, the video's

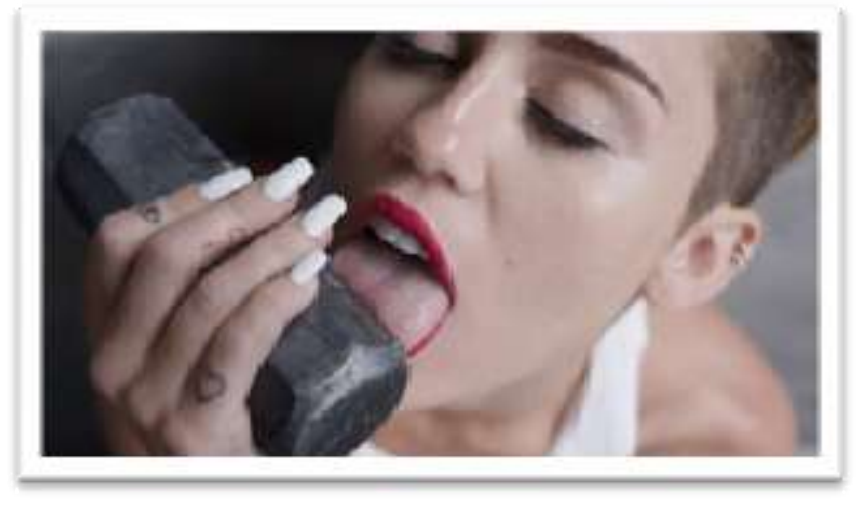

Figure 3: Screenshot from Miley Cyrus' "Wrecking Ball." Cyrus, Miley. "Wrecking Ball.” YouTube. 9 September 2013. Web. 24 October 2014. 〈http://www.youtube.com/watch?v=My2FRPA3Gf8>.

visuals are reminiscent of high resolution fashion magazines, an effect achieved by hiring fashion photographer Terry Richardson as director who transposed the aesthetics of his photographs to the medium of the video clip. Besides those scenes that show Cyrus swinging on a wrecking ball, the clip consists of closeups of Cyrus' face in pale make-up except for her bright red lipstick and medium long shots of the singer imitating fellatio with the tip of a sledge hammer (see 
fig. 3). In addition to overtly alluding to sexual practices, Richardson and Cyrus use more subtle visual markers to charge the shots erotically. The use of contrasting colors and textures as well as reference to established color codes is of special importance in this context. The former is exemplified in the wrecking ball-shots in which Cyrus' immaculately clean, smooth and naked body is set against the background of a smeared, coarse, and partially wrecked video set resembling a construction site (see figure 2). The friction between visual elements is repeated and heightened by the use of color codes in the fellatioshots. Richardson sets the pearly white of Cyrus' fingernails, teeth, and clothes against the bright red lipstick, thus alluding to codes in Western cultures that associate the color red with passion, desire, and sexuality, whereas the color white is associated with purity and innocence. The discord between these connotations - sexuality versus innocence, passion versus purity - not only results in erotically charged images but finds its echo in the media scandal that "Wrecking Ball" created as well.

While Cyrus' video is by no means the only one that portrays the female body near-naked, and arguably not even among the most explicit ones - one recent example of a clip falling into this category would by "Blurred Lines" by Robin Thicke - the fact that Cyrus had risen to fame as a child actor at least in part explains the polarizing effect "Wrecking Ball" had on audiences. From 2006 to 2011, Cyrus had starred in the Walt Disney-produced TV series Hannah Montana in which Cyrus had played a teenage schoolgirl who leads a double-life as a successful singer. In line with the traditionally family-friendly orientation of the Walt Disney Corporation, Cyrus was marketed as an average teenager, 
highlighted in figure 4 through her long blond hair and the overt use of the color pink. Towards the end of Hannah Montana's run, Cyrus had begun to modify her public persona towards a more rebellious and provocative one ${ }^{6}$, a development that culminated in the look she displayed in "Wrecking Ball."

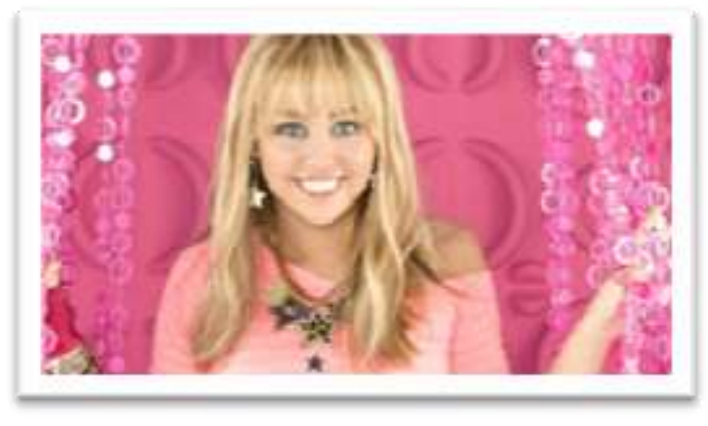

Figure 4: Miley Cyrus as Hannah Montana.

$<$ http://indianexpress.com/article/entertainment/television/miley-said-she-had-to-murder-hannah$\underline{\text { montana-dolly-parton/> }}$

Parallel to this change in public performance from conformist to provocative, the difference between innocence and sexuality is visualized through the use of red and white in "Wrecking Ball," and the disparity between Cyrus new, sexually self-confident public persona and the more innocent one that had made her famous added to the media scandal.

After its release, "Wrecking Ball” polarized audiences. Whereas many fans took no issue with the highly eroticized imagery and saw "Wrecking Ball" as a step of detachment if not liberation from Cyrus' previous public persona as a role model for teenagers; a look into the "Comments" section on YouTube provides countless examples - others were less enthusiastic and skeptical of the

\footnotetext{
${ }^{6}$ For an assessment of this change in Cyrus' public persona that sees a negative effect on teenagers, see Wilson and Anderlik.
} 
direction of Cyrus' development. The debate surrounding Cyrus' video was argued out by participants from different ends of the political spectrum. The conservative Media Research Center for examplee issued a statement bemoaning that Cyrus had become "the epitome of the anti-role model for young girls" (Wilson and Anderlik).

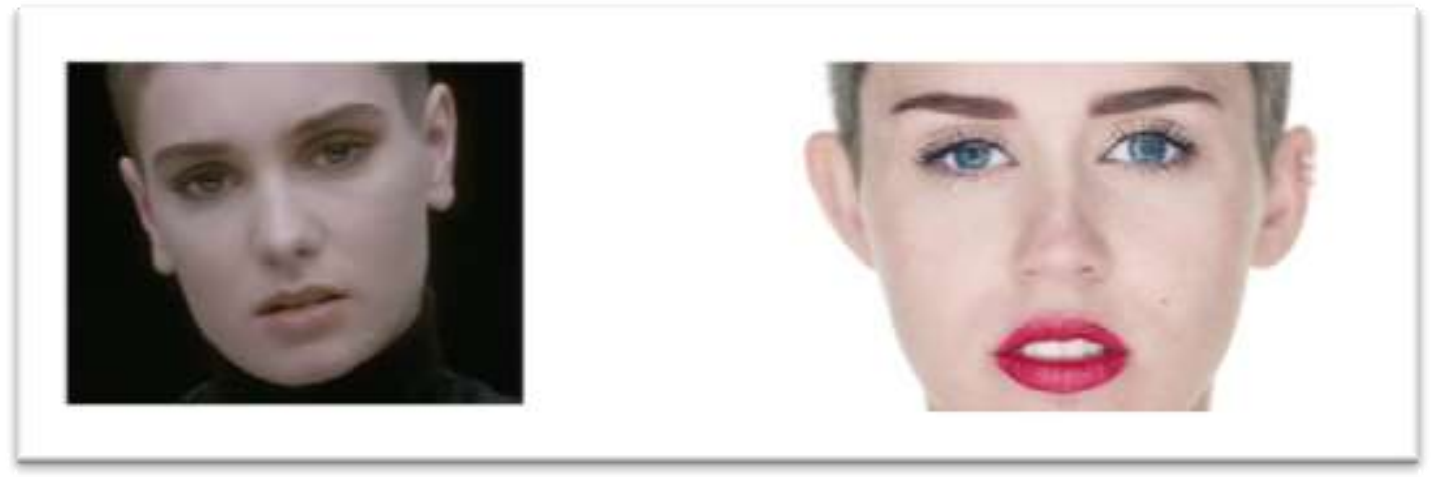

Figure 5 and figure 6: Screenshots from Sinéad O'Connor's "Nothing Compares 2 U" and Miley Cyrus' "Wrecking Ball." O'Connor, Sinéad. "Nothing Compares 2 U." YouTube. 6 March 2009. Web. 24 October 2014. <http://www.youtube.com/watch?v=iUiTQvT0W_0>. Cyrus, Miley. "Wrecking Ball." YouTube. 9 September 2013. Web. 24 October 2014.

〈http://www.youtube.com/watch?v=My2FRPA3Gf8〉.

At the other end of the political spectrum, in a post on The Guardian's music blog, Michael Hann expressed fatigue about the ongoing media controversies7 surrounding Cyrus and also voiced his concern about "the extent of the embrace" of sexualisation Cyrus had taken. More specifically, Hann was critical of the visual referents the pop singer used in "Wrecking Ball" which, he states,

7 In August 2013, Cyrus and Robin Thicke had staged a provocative performance during the MTV Video Music Awards. Cyrus' was scantily clad in underwear and incorporated sexually explicit twerking-dance moves into her show. In addition to the erotically charged provocation of this performance, some observers problematized the alleged racial appropriation Cyrus and Thicke had displayed, given the fact that twerking has its roots in African dances. For a critical comment on the VMA performance with regards to racial appropriation, see Freeman. 
"depicts a woman exploring the iconography of porn." One of the most prominent voices who joined the debate and stated dissent belonged to Irish singer Sinéad O'Connor. O'Connor's contribution is of significance for at least two reasons. Firstly, in an interview with Rolling Stone magazine, Cyrus had explicitly cited O'Connor's video for her 1990 hit "Nothing Compares 2 U” as an inspiration for “Wrecking Ball”: "It's like the Sinead O’Connor video [for "Nothing Compares 2 U”], but, like, the most modern version" (Eells). Echoing the close up on O'Connor's face that constitutes the majority of the video (see fig. 5), Cyrus clip begins with a similar shot (see fig. 6) and goes so far as to later reproduce the tear rolling down O'Connor's cheek that had contributed much to the video's fame. Secondly, O'Connor's contribution to the debate constituted a discursive space in which two female artists from different generations articulated their views on the meaning and figuration of feminism and its artistic expression.

Although Cyrus had mentioned O'Connor as inspiration, the Irish singer was far from flattered. In response to Cyrus' claims to have updated O'Connor's famous video to its “most modern version," O’Connor published an open letter on her website that was reprinted in major newspapers around the globe. In this letter, O'Connor criticized Cyrus' artistic choices and furthermore cautioned her not to be exploited by record industry officials who, as O'Connor put it, "want you because they're making money off your youth and your beauty" (O'Connor). Most importantly, O'Connor stressed the point that the decision to strip in order to promote one's music does not lead to empowerment, but rather objectifies the female body and thus leads to quite contrary results: 
Nothing but harm will come in the long run, from allowing yourself to be exploited, and it is absolutely NOT in ANY way an empowerment of yourself or any other young woman for you to send across the message that you are able to be valued [...] more for your sexual appeal than your obvious talent.

As well intended as O'Connor's intervention might have been, it was also problematic in itself. Its condescending tone - early on in the letter, O'Connor prompts Cyrus to "pay close attention to what I am telling you" (O'Connor) and the fact that she had expressively written it "in the spirit of motherliness" (O’Connor) has been subject of criticism. German journalist Jenni Zylka, to name but one example, pointed out that the fact of being a mother does not automatically result in a morally superior position. ${ }^{8}$ In addition, O'Connor's advice to Cyrus perpetuates a traditional model of feminist generations or waves in the sense that an established feminist artist like O'Connor problematizes contemporary conceptions of feminist art as demonstrated by a young singer like Cyrus. Along the same vein, the verbal exchange between O'Connor and Cyrus at the very least revealed not only contrary conceptualizations of the use of eroticized imagery, but, and this appears to lie at the core of their argument, empowerment as well.

8 “... Das Elternsein qualifiziert einen schließlich nicht per se zum urteilsstärkeren Moralapostel” (“...The fact of being a parent does not per se result in being an opinionated virtuecrat”, Zylka) 
The pairing of empowerment and the use of eroticized imagery has a long history in feminist discourse9, and continues to be both problematic and unresolved, as the case of Cyrus' video exemplifies. I argue that displaying the young, near naked female body in a way that Cyrus has agreed to invite a reading that sees this body as being objectified and thus plays directly into the hands of dominant structures of consumer culture that commodifies the female body in order to sell its products. While there is no reason to question that Cyrus' perceives the display of her body as sexual is for her a sign of selfconfidence as well as a rebellious act against her previous public persona, I remain dubious that the millions of viewers of the video see it in a corresponding manner. Cyrus' attitude towards empowerment that is rather, achieved by utilizing eroticized imagery is a perfect example for a mechanism that Lauren Berlant in her much-discussed book from 2011 has coined cruel optimism. ${ }^{10}$ Berlant states:

A relation of cruel optimism exists when something you desire is actually an obstacle to your flourishing. It might involve food, or a kind of love; it might be a fantasy of the good life, or a political project. [...] They (these relations) become cruel only when the object that draws your attachment actively impedes the aim that brought you to it initially. (1)

\footnotetext{
9 Blandly simplifying, the debate revolves around positions that regard the use of eroticized imagery as an exploitation of women and contrary views that see potential for empowerment if women are in control of said imagery. For an overview of the origins of this debate, see Segal and McIntosh.

${ }^{10}$ See for example Social Text's issue devoted to Cruel Optimism at http://www.socialtextjournal.org/periscope/cruel-optimism/
} 


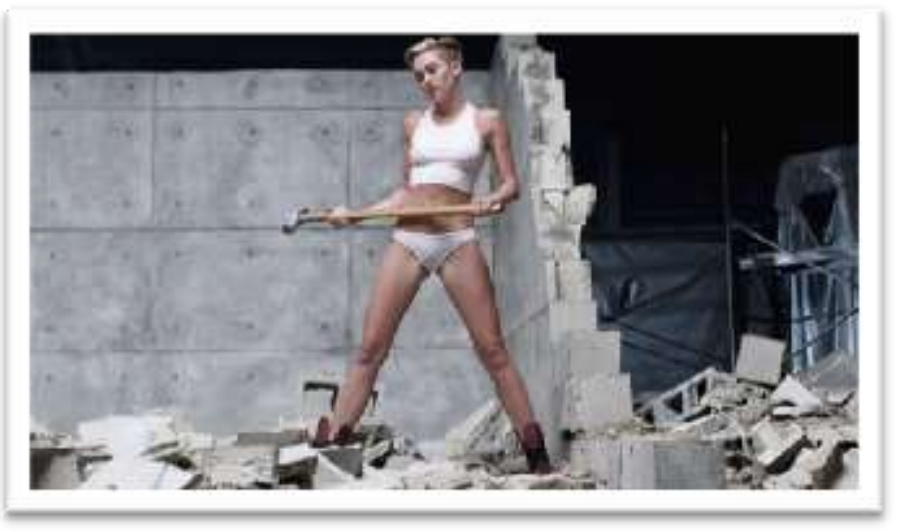

Figure 7: Screenshot from Miley Cyrus" "Wrecking Ball." Cyrus, Miley. "Wrecking Ball." YouTube. 9 September 2013. Web. 24 October 2014. 〈http://www.youtube.com/watch?v=My2FRPA3Gf8>.

The moment Cyrus declares or even only perceives the display of a young nude female body as an act of empowerment - and empowerment certainly is a desirable project - the mechanism of cruel optimism goes into effect and renders this desirable object or condition impossible to obtain. In their analysis of "Awkwardness als Provokation" ("awkwardness as provocation")11, Carrie Smith-Prei and Maria Stehle go one step further and apply the term cruel optimism to the political project of feminism itself: "Die Fragen nach der feministischen Politik fallen in den Bereich des grausamen Optimismus. Feminismus, so unsere These, operiert selbst als grausamer Optimismus" ("Questions of feminist politics fall within the scope of cruel optimism. We argue that feminism itself operates as cruel optimism", Smith-Prei and Stehle 5).) This assertion appears all the more productive when considering that Cyrus

\footnotetext{
${ }^{11}$ Translated from German to English by the author. In an article published in the 2015 Women in German Yearbook, Smith-Prei and Stehle further develop their argument; see Carrie SmithPrei, and Maria Stehle. "WiG-trouble: Awkwardness and Feminist Politics." Women in German Yearbook: Feminist Studies in German Literature \& Culture. 30.1 (2014): 209-224. Print.
} 
has declared herself to be an advocate if not icon of feminism within the discourse evolving around her video. In an interview with the BBC show Newsbeat, Cyrus stated, "I feel like I'm one of the biggest feminists in the world because I tell women to not be scared of anything. Girls are all beautiful" (Harrison). Again, there is no reason to question Cyrus' sincerity. Moreover, a powerful statement like this might even resonate with fans, who not only admire Cyrus' music but continue to perceive her as a role model, a fact that was seen with diligent skepticism in the Guardian blog entry quoted above. Indeed, the use of a wrecking ball and sledge hammer, that is tools used to break down barriers and destroy firmly erected structures, bears a significant amount of potential for a feminist reading of the "Wrecking Ball" video. When Cyrus stands in the midst of ruins, sledge hammer in hand (see fig. 7), the imagery can be interpreted as being charged with rebellious capacity, particularly against the backdrop of Cyrus' attempts to detach herself from her family-friendly image as Hannah Montana. At the same time, I read the video's visuals as being solely focused on Cyrus' self-expression, thus revealing a very personal agenda that, from my point of view, does not allow for a transposition to broader statements about the role of women in art. Even if Cyrus is successful in promoting a new public persona that is contrary to her previously established one, her lascivious body language throughout the video in conjunction with the display of her naked or near-naked body make it hard to read it as an expression of empowerment because very little in the video and nothing in the lyrics of "Wrecking Ball” truly backs up Cyrus' claim of being feminist. On the contrary, one would be hard-pressed to consider lines like "I never meant to start a war / I 
just wanted you to let me in / And instead of using force / I guess I should've let you win" as the expression of a distinctly feminist mindset. To use Berlant's terminology again, Cyrus' video proves to be cruelly optimistic in the sense that her attempts to make a feminist statement falls short due of her willingness to objectify her body without backing up potentially feminist visuals with corresponding content. Put differently, Cyrus stays on the surface of the skin without getting at the levels beneath.

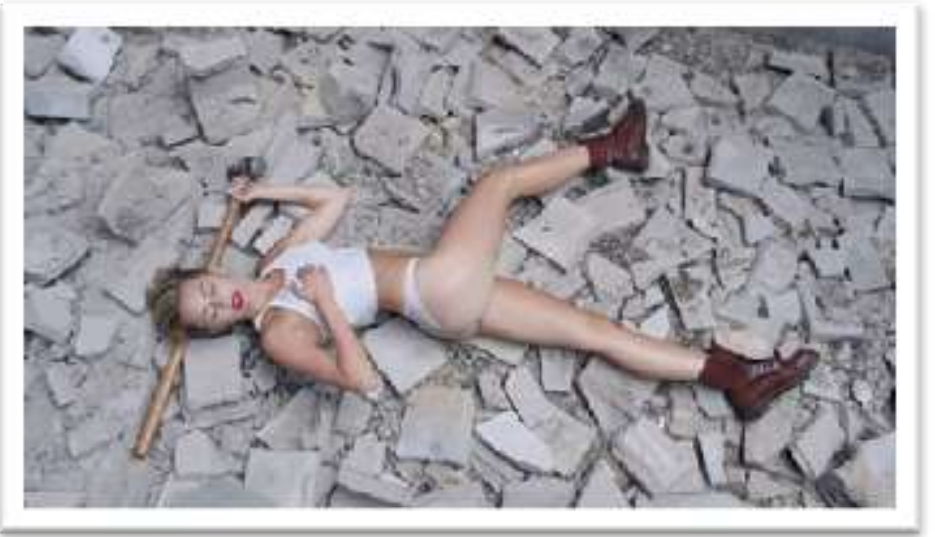

Figure 8: Screenshot from Miley Cyrus' "Wrecking Ball." Cyrus, Miley. "Wrecking Ball." YouTube. 9 September 2013. Web. 24 October 2014. 〈http://www.youtube.com/watch?v=My2FRPA3Gf8>.

When the audience sees Cyrus lying in the ruins of the video set (see fig. 8) in a sexually suggestive pose at the end of "Wrecking Ball," these ruins potentially denote her previous public persona. They cannot, however, be read as the ruins of a status quo in contemporary popular culture that commodifes the young female body. However, Cyrus' well-intended recommendation to girls not to be scared of anything serves to lead to the second female artist I would like to discuss in this article. Twenty-two years before Cyrus, in 1991, Kathleen Hanna 
and her band Bikini Kill gave a similar advice. The form they chose to express it, though, was entirely different.

\section{Rebel Girl - Kathleen Hanna and the Legacies of Riot Grrrl}

The advice I am referring to is found in the opening lines of "Double Dare Ya," the seventh track of Bikini Kill's programmatically titled first release Revolution Girl Style Now. Bikini Kill consisted of lead singer Kathleen Hanna, guitar player Billy Karren, bass player Kathi Wilcox, and Tobi Vail on drums and was of central importance for the development of what later became known as the Riot Grrrl movement. Originally released in 1991, "Double Dare Ya" reappears as the opening track on Bikini Kill's eponymous first E.P. released in 1992. Before the band launches into the song itself, Hanna introduces the band with the self-conscious proclamation "We are Bikini Kill, and we want revolution girl style now," thus unmistakably assuring the listener of the band's political agenda. "Double Dare Ya" opens with the following lines:

Hey girlfriend

I got a proposition goes something like this

Dare ya to do what you want

Dare ya to be who you will

Dare ya to cry right out loud

You get so emotional baby

Double dare ya, double dare ya, double dare ya

Girl fuckin friend yeah. (Bikini Kill) 
Even though the message is - at least at a first, cursory look - very similar to Miley Cyrus' assurance that girls should not be afraid of anything, the harsh, rudimentary sound of punk rock that is the acoustic background of Bikini Kill's statement stands in stark contrast to Cyrus' radio-friendly pop geared towards reaching a mass audience. In addition, on a linguistic level, the repeated use of the verb "to dare" in connection with the colloquial form "ya" ("I") as the firstperson pronoun charges the language with an imperative character that adds a layer of urgency missing from Cyrus' declaration. That being said, a closer look at Bikini Kill's lyrics furthermore reveals that "Double Dare Ya" has an agenda that differs significantly from Cyrus' assertion that "girls are all beautiful." All dares mentioned in Bikini Kill's song - be who you will, cry out loud and so forth - refer to concepts of identity construction instead of the surfaces of the body and thus challenge the listener to question what mainstream society regards as stereotypically feminine. It is this focus on deconstructing, blurring, and re-shaping notions of femininity - and, more generally, gender - that was one of the tenets of the Riot Grrrl-movement for which Bikini Kill contributed a soundtrack.

Echoes of the punk subculture of the 1970 s in the Riot Grrrl-movement is of special importance, not least because the Riot Grrrls contested the "hegemonic masculinity" (Williams 58) displayed within the punk subculture of the 1990 . When using the term "subculture," I refer to Williams' interactionist definition of the concept, who states: 
Subcultures refer to culturally bounded, but not closed, networks of people who come to share the meaning of specific ideas, material objects, and practices through interaction. Over time, their interactions develop into a discourse and culture that shapes, but not determines, that generation, activation, and diffusion of these ideas, objects, and practices. (39)

In her 2010 history of the movement, Girls to the Front, Sara Marcus sheds light on the sociopolitical and aesthetic backgrounds that provided the soil on which the Riot Grrrl-movement first grew in the Pacific Northwest and Washington, D.C. According to Marcus, the liberal Evergreen State College which Hanna and many of her fellow activists attended - among them Bikini Kill's drummer Tobi Vail and Carrie Brownstein of Sleater-Kinney — had a positive effect on the development of what Marcus describes as "a self-sufficient and decidedly all-ages musical culture” (37) that allowed for artistic experiments beyond the pressure of commercial success. Roughly twenty years after its initial emergence in New York and London respectively, punk subculture had a revival in the Pacific Northwest, and Olympia turned out to be one of its epicenters:

By the end of the ' 80 s, the town's punk scene was thriving, even magical. "Punk" here meant not mohawks and spikes but do-it-yourself, or DIY: creating something from nothing, fashion from garbage, music and art from whatever was nearest at hand [...]. DIY was a philosophy and a way of life, a touchstone that set its industrious adherents apart from the legions of Americans who passed their lives - as the punks saw it - trudging from TV set to first-run multiplex, from chain record store to commercial radio dial, treating art and cultures as commodities to be 
consumed instead of vital forces to be struggled with and shaped, experimented and created, breathed and lived. (Marcus 37)

Marcus' description highlights the reference to punk's DIY-aesthetics and a generally critical, more specifically expressively anti-consumer attitude as two principles of the Riot Grrrl-movement. However, just like most other social, political or artistic movements, the Riot Grrrls drew their momentum from a variety of sources. Characterizing the movement with an encyclopedia clear-cut definition of the term is rather futile, though, and neglects the fact that "Riot Grrrl is foremost about process, not product; it's about the empowerment that comes from 'getting up and doing it"' (Reynolds and Press 327). In another attempt to capture the most important characteristics of the movement, Rachel Smith writes in an article that revisits Riot Grrrl twenty years after its inception, "it was a self-conscious rejection of polish in favour of immediacy and spontaneity - a revolution you could dance to" (Smith). While this quote again points out the anti-consumer ideology and adds an element of joyous celebration, it is imperative to mention that the Riot Grrrl-movement resulted from fear, anger, and the urgency to speak out against the ever increasing numbers of sexual assaults in the 1990s (Marcus 113) as well. As mentioned above, and this is of equal importance for the feminist undercurrent of the movement, it was also directed against male dominance in art and specifically music. Hanna put this into practice by reserving the space in front of the stage for female audience members only. While being expressively feminist - at least for some of the activists involved - Riot Grrrl at the same time spawned from 
dissatisfaction with, if not disillusion from, the second wave feminism of the 1970s:

Teenage girls were simply living some of the thick residuals of sexism the feminist movement hadn't managed to destroy. Rigid gender roles were alive and well and forced on girls as they hit puberty, which was especially difficult for children of the '70s to swallow. Many of the Riot grrrls had been taught by at least somebody - if not a parent, then a supportive teacher or coach - that they could do anything they wanted, and that there were no barriers. Then they found out it wasn't true. (Marcus 113-114) $^{12}$

In sum, it is perhaps most important to note that Riot Grrrl can be considered as a decidedly feminist figuration of the punk subculture. In Anderson's documentary The Punk Singer, Hanna explicitly recalls that one of Bikini Kill's goals was to "take over the punk rock scene for feminists" (Anderson, The Punk Singer). Not least, the subcultural background of Riot Grrrl was of special significance because subcultures are able to open up spaces of identity construction, cultural participation, and artistic experimentation not offered by mainstream, male-centered society. This is all the more central to the female participants in Riot Grrrl because, as J. Patrick Williams puts it in his introduction to subcultural theory, "women's subcultural participation may be seen as a form of feminist activity. Women often report participating because of a desire to find different sources of self-esteem and social comparisons from

\footnotetext{
${ }^{12}$ See also Reynolds and Press: "Finally, there's a post-feminist strand running through Riot Grrrl ideology. While a lot of the Riot Grrrls refuse to align themselves with feminism, many have mothers who were involved in the first and second waves of feminist movement" (324).
} 
those of the mainstream, which emphasize a narrow range of acceptable feminine attributes (e.g., physical attractiveness, nurturing attitudes) and behaviors (e.g., "traditional" gender roles and sexuality)(58).

Within this subcultural atmosphere of creativity and resistance to mainstream culture outlined above, Kathleen Hanna as the lead singer of Bikini Kill and the head behind the eponymous fanzine soon became an important and outspoken proponent of Riot Grrrl ideology. In line with studies that show that participants do not necessarily cease to engage in subcultural practices once they get older ${ }^{13}$, in her work as singer of The Julie Ruin, Kathleen Hanna today still displays aesthetic choices and artistic approaches that are informed by her history in the Riot Grrrl movement. My argument here is that artists like Hanna who come with a rich history of feminist practices that in turn are informed by having been situated at the fringes of mainstream society, are better suited to challenge the status quo of cultural production than artists like Cyrus who follow cruelly optimistic approaches.

On a visual level, the simple DIY-look that was characteristic for the heyday of the Riot Grrrls resonates in the imagery of The Julie Ruin's “Oh Come On.” As briefly outlined in the introduction, the video's visual style, despite the blinking Christmas lights, is nowhere near the glossy look of "Wrecking Ball," and instead of using eroticized imagery, the clip limits itself to presenting the band playing the song. While this certainly has to be attributed to the audience The

\footnotetext{
${ }^{13}$ Research on the relationship between subcultural participation and age is steadily growing;
} for just two examples that address the topic, see Bennett (2006), and Hodkinson (2013). 
Julie Ruin is trying to reach, I also read this focus on the music instead of visual exuberance as a continuation of the subcultural aesthetics and ideology of the Riot Grrrls which by the twenty-first century has become part of a continuum of feminist practices in art and culture. To exemplify both the practices and the establishment of a feminist continuum further, it was one of Hanna's habits while being in Bikini Kill to wear short tank tops on stage and write provocative terms like "Slut" or "Whore" on her exposed skin (see fig. 9). The purpose of this was to humorously address the objectification of the female body in popular music by confronting potential voyeurs in the audience - or, to use a term from above mentioned feminist continuum, the 'male gaze' - with their perception of the female body on stage. ${ }^{14}$ According to Hanna, "'When you take off your shirt [on stage] the guys think “Oh, what a slut" and it's really funny because they think that and then they look at you and it says it"' (Reynolds and Press 325). Twenty years later, feminist grassroots protest would pick this up. During the Slutwalks, protest marches directed against the excuse of rape based on the victim's alleged sexually provocative appearance, women dress deliberately in a "provocative" manner and confront onlookers with messages written on their exposed skin (see fig. 10). Using the body as the canvas for protest messages is also one of the defining features of FEMEN, a feminist activist group that originated in Ukraine and now has branches all over the world. ${ }^{15}$ Not least, the Russian art collective Pussy Riot who in 2012 gained significant popularity with

\footnotetext{
${ }^{14}$ See Laura Mulvey "Visual Pleasure and Narrative Cinema" (1975) in Amelia Jones (ed.) The Feminism and Visual Culture Reader. London: Routledge, 2003. 44-52. Print. ${ }^{15}$ See Marine Gheno's analysis of the reception of FEMEN within the French context in this volume of Multilingual Disourses.
} 
their "punk prayer" directed against Vladimir Putin references Riot Grrrl both in their name and in using punk as their means of expression for their protest. Significantly, the mark Riot Grrrls have doubtlessly left on the continuum of feminist resistance to heteronormative mainstream culture also resonated in the controversy around Miley Cyrus' video.

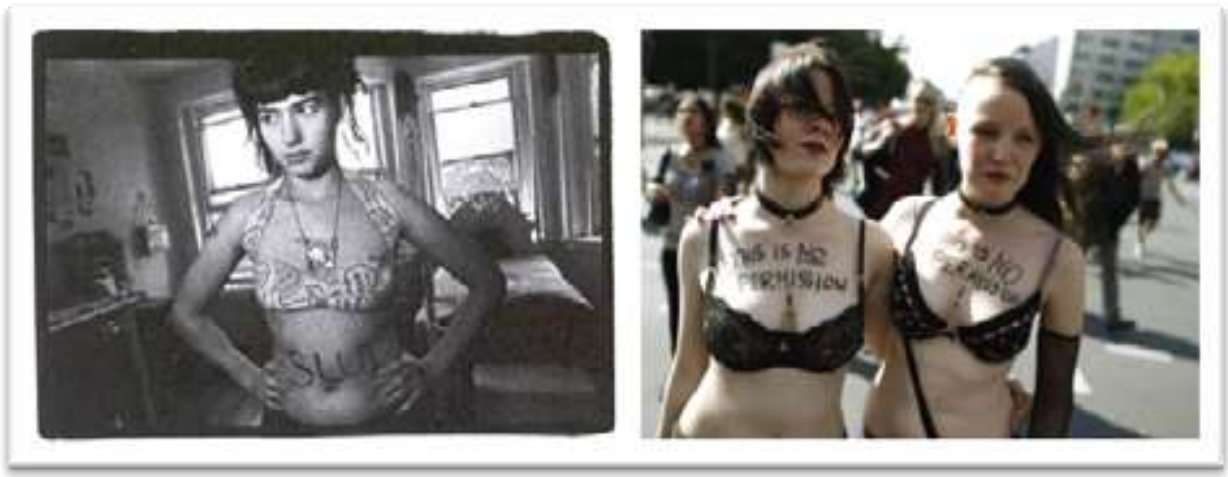

Figure 9 and figure 10: Kathleen Hanna, participants of Slutwalk Berlin, 2011. Faulkner, Noelle. "Kathleen Hanna: A Cheat Sheet (And Why Everyone Is Talking About Her." Elle.com. 6 August 2014. Web. 24 October 2014. <http://www.elle.com.au/pop-culture/hot-list/2014/8/kathleenhanna-a-cheat-sheet/>. Suh, Anne. "SlutWalk Rally Against Sexual Abuse and Inequality in Central Berlin.” Ibtimes.com. 13 August 2011. Web. 24 October 2014.

$<$ http://www.ibtimes.com/slutwalk-rally-against-sexual-abuse-and-inequality-central-berlin$836737>$.

In her comment on the "Wrecking Ball" scandal, The Guardian-columnist Daisy Buchanan came to the following conclusion: "We need to search for and celebrate contemporary musicians who invoke the spirit of the Riot Grrrl movement; otherwise the girls that need them most will never find them" (Buchanan PAGE). While a reformulation of the ideas and ideals of the Riot Grrrls for the $21^{\text {st }}$ century might indeed open up new possibilities for female artists in popular music that go beyond the ever persistent objectification of their body, this quote bears uncanny resemblance with Sinéad O'Connor 
condescending open letter to Miley Cyrus. Moreover, it shows very little trust in "the girls who need them most." Instead, I would urge Buchanan to have more faith in the ability of teenagers and young adults to find those artists on their own. In fact, they are already in the process of being found while I am writing this article for at the margins of mainstream cultural production, where the origins of 1990 os Riot Grrrl culture emerged, feminist art appears to be alive and well.

To name but one example of a feminist artist who continues the legacies of Riot Grrrl in the context of today's media society, NYC-based artist Lauren Denitzio explicitly addresses issues of feminism, economic and social precarity, and sexism. Next to her musical output, Denitzio is also a visual artists and installations like her 2012 "A Place Outside Patriarchy That Does Not Exist” (see fig. 11) are proof that, following the Riot Grrrl's tradition to augment the messages transported in their music through complementary visual art in their fanzines, the intermedial aspect of politically charged art is still fruitful today. As a musician, Denitzio heads the punk rock band Worriers. In an effort to keep alive a feminist continuum within popular music, Denitzio’s song "Sinéad O'Rebellion" references the rebellious spirit of the Irish singer in the title. It positions the lyrical "I" in line with a tradition of feminist protest, in this case by alluding to O'Connor's infamous Saturday Night Live performance in 1992 during which she tore up a picture of the pope: "I align myself with the likes of those who rip up photos on broadcast TV” (“Sinéad O'Rebellion”). By writing lines like this, Denitzio unambiguously positions herself on the continuum of political feminist art populated by O'Connor, Hanna, and other artists still 
active today. Of equal importance is the fact that Denitzio acknowledges the continuum and evidently sees the worth of continuing this history in the context of today's media. Denitzio and her band also notably demonstrated their familiarity with the contemporary theoretical background of feminism by calling their first full-length album from 2013 Cruel Optimist, thus referencing Lauren Berlant in both the title of their album and within their lyrics as well when Denitzio sings about the false promises of the "good life."

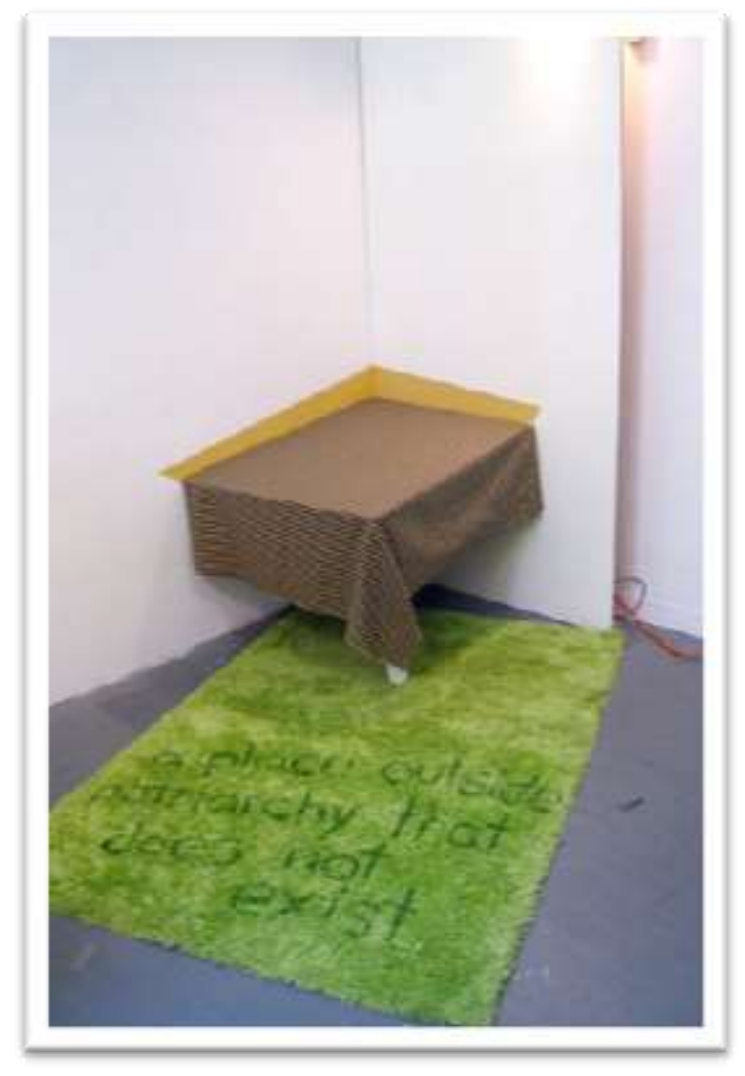

Figure 11: Lauren Denitzio's “A Place Outside Patriarchy That Does Not Exist." <http://blackandredeye.com/index.php/a-place-outside-patriarchy>.

Not least, as a further testament to a resurgence of feminist ideas in popular music, seminal Riot Grrrl band Sleater-Kinney in January 2015 released their 
album No Cities to Love, their first after a hiatus that lasted for a whole decade. It appears that not only the 1990 s are back, as Hanna has stated in an interview (“+1”) but central figures of the Riot Grrrl movement as well.

\section{Conclusion: "I align myself with the likes of those..."}

The examples of Hanna and Sleater-Kinney returning to the musical scene while artists like Lauren Denitzio carry on a tradition of feminist art that first peaked in the 1990 demonstrate that things do not look quite as grim as one would think in light of videos like "Wrecking Ball" or the notorious "Anaconda" by Nicki Minaj. Kathleen Hanna, for one, is in fact rather optimistic about the state of feminism in contemporary popular music. In an interview with the Pitchfork.tv, she has stated that,

I think there is a lot of exciting stuff happening now. I feel like because we're more likely to cite each other as influences, it creates a continuum, like a feminist continuum within music, and I think that's really really positive. And it all doesn't have to sound like militant feminism or separatist feminism or Marxist feminism, it doesn't even have to have the word 'feminist' used. You know, I think it's just exciting that it's not that weird to be a woman in a band anymore. (“+1”)

One has to agree with Hanna that in 2014, it is indeed "not that weird" for women to express themselves through music, and it is imperative to emphasize that this is far from being trivial. The diffusion of aspects of the Riot Grrrl ideology into the mainstream has paved the way for female artists to increasingly occupy spaces within cultural production and, in the process, 
heighten the visibility of feminist art. By 2015, the spectrum of female artists who successfully claimed their place within rock music ranges from more established singers like Ani DiFranco and Polly Jean Harvey to younger artists like Denitzio and other Riot Grrrl-influenced acts like Girlpool who are yet operating at the peripheries of the mainstream music industry. In this respect, the Riot Grrrl's slogan "girls to the front" can be read quite literally and is constantly being answered, regardless of cruelly optimistic setbacks I have addressed earlier.

Hanna's assessment appears to point into a less ideologically charged direction of feminist interventions that do not necessarily have to go back to the more separatist qualities ${ }^{16}$ of Riot Grrrl. Still, the question remains whether a 'subdued' version of popular music with a feminist agenda that does not come from the subcultural fringes of our media society can have a similarly long-term impact than the Riot Grrrls had. Simply stating, as in the case of Cyrus, "I am a feminist artist" without backing this claim up with at least some sort of political content or by using imagery that even seems to contradict this claim, does not seem to be a promising way for the future and will remain in the realm of selfexpression. Instead, I suggest that keeping the continuum of feminist art alive still requires interventionist practices that question and trouble the status quo of male dominance and heteronormativity within the culture industry. Going back to some of the Riot Grrrls practices and adopting them for the current figuration of the popular music scene is fruitful because these practices are

\footnotetext{
${ }^{16}$ See also Reynolds and Press, especially p. 324.
} 
aimed at challenging male dominance and the way female bodies are displayed, to name but two examples. Moreover, the fact that the return of Kathleen Hanna and Sleater-Kinney has triggered considerable mainstream media attention suggests a fatigue with the cruelly optimistic approaches exemplified through artists like Cyrus while at the same time, as in the case of The Guardian's Daisy Buchanan, expressing the desire for alternative takes on feminist art. Artists like Lauren Denitzio prove that popular music that does come with some theoretical background still has its place on the continuum of feminist art as well, especially if it explicitly aligns itself with this continuum and history. After all, taking one step back can sometimes mean taking two steps forward.

These options in themselves open up possibilities for the future, even if they come in the form of unlikely alliances. On July 31, 2014, Miley Cyrus posted with praise two pictures of Kathleen Hanna from her time as Bikini Kill's lead singer on her Instagram account, one of them being the one on which Hanna has written "Slut" across her body (see fig. 9) with the added caption "coolest ever" (Pelly). Whereas Hanna had previously been less kind to some of Cyrus' contemporaries ${ }^{17}$, her reaction this time went in the opposite direction. In Hanna's response to Cyrus' post via Twitter, she suggested a collaboration: “Hey @MileyCyrus so sweet you posted pics of me... have an idea for an album that only you are daring enough to make"-which lead online music magazine Pitcfork.com to express the hope Cyrus and Hanna would record as "Kathleen

\footnotetext{
17 In an interview with CNN in 2011, Hanna commented on pop singer Katy Perry's song "I Kissed a Girl”: "But (Katy Perry's) "I Kissed a Girl” was just straight-up offensive. The whole thing is like, I kissed a girl so my boyfriend could masturbate about it later. It's disgusting. It's exactly every male fantasy of fake lesbian porn" (Goodman).
} 
Hannah Montana" (Pelly). Regardless of whether this collaboration some day comes into fruition or not, a number of aspects make a joint effort of Hanna and Cyrus an intriguing prospect. For one thing, it would result in a partnership between two generations of feminist artists, which, as the example of the argument between O'Connor and Cyrus has shown, more often than not fails to be established due to conflicting views and different political agendas. Additionally, collaborating with Hanna could enable Cyrus to broaden the scope of her artistic practices, thus potentially filling the content-void I have criticized above in my reading of "Wrecking Ball." Not least, this would be promising because of Cyrus' status within the landscape of popular music today which would guarantee a huge audience. Injecting Cyrus' work with Riot Grrrlpractices and content has the potential to truly challenge the status quo of women within cultural production. It would confront a mainstream audience with ideologies from the subcultural fringes of the music industry and I express the hope that people will listen. The effects on the audience are as unpredictable as the outcome of a potential collaboration between Cyrus and Hanna. However, the idea of equipping the rebel girls with a wrecking ball seems to be a promising idea to define what "Revolution Girl Style Now" could mean in the $21^{\text {st }}$ century. 


\section{Postscript}

By the time this article has undergone the review process for this issue of Multingual Discourses, a new video has been released by Miley Cyrus that almost seems as an anti-thesis to "Wrecking Ball." As if to answer the call for more feminist content and unlikely alliances, Cyrus has recorded a cover of The Replacement's “Androgynous” with Joan Jett and Laura Jane Grace to promote Cyrus' charity organization "The Happy Hippie Foundation”. The lyrics of the song discuss the fluidity of gender constructions and thus go down a completely different path than the heteronormativity Cyrus had demonstrated in "Wrecking Ball." While the deadline of this issue does not allow for a thorough analysis of Cyrus' move, there is now reason to believe that we are in the process of witnessing a rebel girl in the making and further proof that "Revolution Girl Style Now" has lost none of its meaning. 


\section{Works Cited}

“+1: The Julie Ruin.” Pitchfork.tv. 13 August 2013: n.pag. Web. 24 October 2014 .

Anderson, Sini, dir. The Punk Singer: A Film about Kathleen Hanna. MPI Media, 2014. DVD.

Bennett, Andy. "Punk's Not Dead: the Continuing Significance of Punk Rock for an Older Generation of Fans.” Sociology. 40.2 (2006): 219-235. Print.

Berlant, Lauren. Cruel Optimism. Durham: Duke University Press, 2011. Print.

Bikini Kill. "Double Dare Ya." The CD Version of the First Two Records. 1991. Kill Rock Stars, 2012. MP3.

Breihan, Tom. “Pussy Whipped Turns 20.” Stereogum.com. 28 October 2013: n. pag. Web. 24 October 2014.

Buchanan, Daisy. "Forget 'Empowered' Pop Stars - We Need More Riot Grrrls.”

Theguardian.com. 17 October 2013: n.pag. Web. 24 October 2014.

Cyrus, Miley. “Wrecking Ball.” YouTube. 9 September 2013. Web. 24 October 2014.

Cyrus, Miley, Laura Jane Grace, and Joan Jett. “Androgynous.” YouTube. 9 May 2015: n. pag. Web. 27 May 2014.

Darms, Lisa, and Johanna Fateman. The Riot Grrrl Collection. , 2013. Print.

DeVille, Chris. "Sleater-Kinney Announce No Cities To Love Reunion Album \& World Tour.” Stereogum.com. 20 October 2014: n. pag. Web. 24 October 2014. 
Eells, Josh. "Miley Cyrus on Why She Loves Weed, Went Wild at the VMAs and Much More.” Rollingstone.com. 27 September 2013: n. pag. Web. 24 October 2014 .

Freeman, Hadley. "Miley Cyrus's Twerking Routine Was Cultural Appropriation at its Worst." Theguardian.com. 27 August 2013: n.pag. Web. 24 April 2015.

Goodman, Abbey. "The Original Riot Grrrl on Katy Perry, 90’s Revival.” Cnn.com. 7 June 2011: n.pag. Web. 27 October 2014.

Gordon, Kim. "Kim Gordon Chats With Kathleen Hanna: Uncut Version!" bust.com. 24 October 2013: n. pag. Web. 24 October 2014.

Haddow, Douglas. “The Real Controversy of MIA's Video.” Theguardian.com. 1 May 2010: n. pag. Web. 24 October 2014.

Hanna, Kathleen. “Hey @MileyCyrus so sweet you posted pics of me...have an idea for an album that only you are daring enough to make." 4 August 2014, 6:35 p.m. Tweet.

Hann, Michael. "Miley Cyrus's New Wrecking Ball Video Says Young Women Should BSexually Available.” Theguardian.com. 10 September 2013: n.pag. Web. 24 October 2014.

Harrison, Lily. "Miley Cyrus Talks Double-Standards: 'I Feel Like I'm One of the Biggest Feminists in the World'." eonline.com, 14 November 2013: n.pag. Web. 5 February 2014.

Hodkinson, Paul. "Spectacular Youth Cultures and Ageing: Beyond Refusing to Grow Up.” Sociology Compass. 7.1 (2013): 13-22. Print.

Marcus, Sara. Girls to the Front: The True Story of the Riot Grrrl Revolution. New York: Harper Perennial, 2010. Print.

O'Connor, Sinéad. "Nothing Compares 2 U.” YouTube. 6 March 2009: n.pag. Web. 24 October 2014. 
---. "Open Letter to Miley Cyrus." theguardian.com, 3 October 2013: n. pag. Web. 5 February 2014.

Pelly, Jenn. "Kathleen Hanna Reaches Out To Miley Cyrus For Collaboration After Miley Instagrams Bikini Kill Pics.” Pitchfork.com. 4 August 2014: n. pag. Web. 24 October 2014.

Reynolds, Simon. Retromania: Pop Culture's Addiction to Its Own Past. London: Faber \& Faber, 2011. Print.

Reynolds, Simon, and Joy Press. The Sex Revolts: Gender, Rebellion, and Rock 'n' Roll. Cambridge, Mass: Harvard University Press, 1995. Print.

Segal, Lynne, and Mary McIntosh. Sex Exposed: Sexuality and the Pornography Debate. New Brunswick, N.J: Rutgers University Press, 1993. Print.

Smith-Prei, Carrie and Maria Stehle. "Awkwardness als Provokation.” Fiktionen Und Realitäten: Schriftstellerinnen Im Deutschsprachigen Literaturbetrieb. Eds. Brigitte E, Jirku and Marion Schulz. Frankfurt am Main: Peter Lang Edition, 2013. 301-316. Print.

Smith, Rachel. "Revolution Girl Style, 20 Years Later.” NPR.org, 22 September 2011: n. pag. Web. 5 February 2014.

The Julie Ruin. "Oh Come On.” YouTube. 5 August 2013. Web. 24 October 2014 .

"The Most Popular Music Video of 2013 Is Miley Cyrus' Wrecking Ball." News.com.au. December 9 2013: n. pag. Web. 24 October 2014.

Williams, J P. Subcultural Theory: Traditions and Concepts. Cambridge, UK: Polity Press, 2011. Print.

Wilson, Paul, and Joe and Betty Anderlik. "Hollywood Promoting Women Behaving Badly." MRC Culture.com. 26 January 2012: n.pag. Web. 24 April 2015 .

Worriers. “Sinéad O’Rebellion.” YoYo Records, 2013. MP3. 
Zylka, Jenni. "Von Porno keine Spur." Spiegel Online, 10 October 2013: n.pag. Web. 5 February 2014.

Lars Richter is a PhD candidate in German Languages and Literatures at the University of Alberta in Edmonton. He studied German and English at Freie Universität in Berlin and achieved his M.A. in German at Washington University in St. Louis. His research interests are contemporary German literature and culture, popular culture, film, gender studies, and subcultural theory. Lars' dissertation focuses on the works of German author Juli Zeh. lars.richter@ualberta.ca 